\title{
Preliminary Assessment of the Impact of Current Flooding Practices on Nonstructural Carbohydrate Concentrations of Cranberry
}

\author{
Michelle R. Botelho and Justine E. Vanden Heuvel
}

\begin{abstract}
ADDITIONAL INDEX WORDS. Vaccinium macrocarpon, respiration, temperature
SUMmARY. American cranberry (Vaccinium macrocarpon) production sites are often flooded for pest control and crop harvest. However, little is known about how this practice affects vines. A survey was conducted in Massachusetts over a 3-year period to determine the effect of spring, fall, and winter floods on total nonstructural carbohydrate concentration (TNSC) of cranberry uprights of four cultivars. With a few exceptions, TNSC generally was unaffected or increased during the course of the 1-month "late water" flood held from mid-April to midMay. The 48-hour "flash" flood, held in mid- to late May, generally had little effect on vine TNSC. Fall "harvest" floods, which ranged in duration from 3 to 27 days, often resulted in a decrease in TNSC, with greater decreases in TNSC occurring in early fall floods compared to late fall floods. Decreases in TNSC during the harvest flood were as great as $42 \%$. "Winter" floods had little effect on TNSC. Path coefficient analysis indicated that flood duration, date of application, water temperature, and dissolved oxygen concentration all impacted vine TNSC during the flood, while floodwater depth had little effect. Water clarity (i.e., light penetration to the vines during the flood) also appeared to have little impact. Due to the frequent observation of TNSC decline during fall flooding, it is possible that yield potential of cranberry vines is reduced by current flooding practices.
\end{abstract}

$\mathrm{T}$ The american cranberry, a commercially grown fruit native to bogs of eastern North America, is a low-growing, vine-like woody perennial that forms a dense mat on the soil surface (Eck, 1990). Short vertical stems, known as uprights, arise from the vine or from older uprights (Eck, 1990). Although individual uprights bear fruit biennially, overall yield does not usually alternate due to large upright populations found on cranberry beds (Roper and Vorsa, 1997). Fruit set is the most important component in cranberry yield (Baumann and Eaton, 1986). Flowering uprights bloom acropetally, and failure of upper fruit development on an upright is likely due to depletion of carbohydrate resources during the initial stages of fruit set (Birrenkott and Stang, 1990). Low fruit

University of Massachusetts-Amherst, Cranberry Experiment Station, 1 State Bog Rd., PO Box 569, E. Wareham, MA 02538.

This research was supported by USDA/CSREES, the Massachusetts Agricultural Experiment Station Project MAS00875, the Cape Cod Cranberry Growers' Association, Ocean Spray Cranberries Inc., and the Cranberry Experiment Station. We gratefully acknowledge the technical assistance of Amber Awad, as well as the A.D. Makepeace Co., Mann Farms, Cranberry Hill, and the Ward family for providing sites for this study. We thank Kevin Kosola, Wesley Autio, and Carolyn DeMoranville for their assistance with this manuscript. set (Roper and Vorsa, 1997), biennial bearing (Birrenkott etal., 1991; Striket al., 1991), and low carbohydrate concentrations at the beginning of fruit set (Hagidimitriou and Roper, 1994) are some indications that cranberry vines are under constant carbohydrate stress. A significant cause of carbohydrate stress in vines may be prolonged periods of net respiration during flooding (Botelho and Vanden Heuvel, 2005; Vanden Heuvel, 2005).

Flooding is a common management tool used by cranberry growers for several beneficial purposes. "Winter" floods are used for protection against dry winter winds in cold climates (i.e., Massachusetts, New Jersey, and Wisconsin). "Late water" (LW) and "flash" floods are used for weed reduction and pest control (Averill et al., 1997; Cockfield and Mahr, 1992; Marucci and Moulter, 1971). "Harvest" floods are used as a means to harvest fruit and remove fallen leaves, and are sometimes extended to control insects and weeds. Current recommendations for flooding in Massachusetts include a possible 1 -month flood in the early fall to assist with the control of cranberry fruitworm (Acrobasisvaccinii) and dewberry (Rubus hispidus) (DeMoranville et al., 2005).

Dormant cranberry vines are more flood tolerant than actively growing vines, and can survive several months of submergence under a winter flood, when soil and plant temperatures are low (Crane and Davies, 1989). Conversely, vines are severely damaged by short-term flooding during the growing season, when temperatures are high (Stevens and Thompson, 1942). Water temperature (Vanden Heuvel, 2005) and dissolved oxygen (DO) concentration (Botelho and Vanden Heuvel, 2005) likely play a large role in the effect of flooding on the vines. However, lack of research regarding risks associated with flooding and the physiological effects of flood application on vines has resulted in growers and extension personnel making educated guesses at best-management practices. Further investigation is needed to update current recommendations to growers regarding flooding practices.

Investigating the effect of floods on field-grown cranberry vines with proper replication is difficult. It is impossible to replicate flooding treatments on a production bed, as every bed within a group will typically be flooded. Comparisons may be made on a site-to-site basis (Averill et al., 1997); however, there is a great deal of variation between sites with respect to management practices, as well as vine age and health. One factor that can make site-to-site comparisons even more difficult is distance between comparison sites, as greater distances between comparison units increase the likelihood of variation in the field. While controlled environment studies provide some insight into flooding effects on cranberry vines (Botelho

\begin{tabular}{llll}
\hline $\begin{array}{l}\text { Units } \\
\begin{array}{l}\text { To convert U.S. to SI, } \\
\text { multiply by }\end{array}\end{array}$ & U.S. unit & SI unit & $\begin{array}{l}\text { To convert SI to U.S., } \\
\text { multiply by }\end{array}$ \\
\hline 0.0929 & $\mathrm{ft}^{2}$ & $\mathrm{~m}^{2}$ & 10.7639 \\
2.54 & inch $(\mathrm{es})$ & $\mathrm{cm}$ & 0.3937 \\
28,350 & $\mathrm{oz}$ & $\mathrm{mg}$ & $3.5274 \times 10^{-5}$ \\
1 & $\mathrm{ppm}$ & $\mathrm{mg} \cdot \mathrm{L}^{-1}$ & 1 \\
$\left({ }^{\circ} \mathrm{F}-32\right) \div 1.8$ & ${ }^{\circ} \mathrm{F}$ & ${ }^{\circ} \mathrm{C}$ & $\left(1.8 \times{ }^{\circ} \mathrm{C}\right)+32$
\end{tabular}


and Vanden Heuvel, 2005; Vanden Heuvel, 2005), they may simplify a complex situation.

The objective of this research is to update current recommendations to growers regarding flooding practices by tracking seasonal carbohydrate levels and identifying abrupt changes that may be due to flooding.

\section{Materials and methods}

Plant material-Seasonal CarBOHYDRATE TRACKING. 'Stevens' and 'Early Black' uprights were each collected from a research site and a commercial site located in East Wareham, Mass. (lat. $41^{\circ} 45^{\prime} \mathrm{N}$, long. $70^{\circ} 40^{\prime} \mathrm{W}$ ) (Site 12 and Site 7, respectively) during the 2003 and 2004 growing seasons. The cultivars were located on the same bed at each site and, therefore, received the same flooding treatments. At each site, a portion of the bed was divided into four $25-\mathrm{m}^{2}$ repetitions, from which two subsamples were collected randomly for a total of eight subsamples per sample date. Tissue samples, including above-ground (uprights and woody stems) and below-ground (roots and below-ground woody stems) growth, were collected on a monthly basis from Apr. 2003 through Nov. 2004. Samples were also collected prior to and immediately following all flood events ("flash," "harvest," and "winter" floods).

Plant material-Commercial SITE FLOOD SAMPLES. LW floods were monitored at six sites, one of which was sampled for 2 years. Seven flash flood sites were studied over a 2-year period. Harvest floods were investigated at 17 sites, many of which were sampled over multiple years, for a total of 29 harvest floods. Above-ground tissue samples were collected pre- and post-flood. At these locations, repetitions were chosen based on the natural formation of a bed (i.e., location of interior ditches) and ranged from approximately 25 to $100 \mathrm{~m}^{2}$ among sites, but were generally consistent in size within a site. Eight subsamples were removed from each site immediately prior to and following each flood.

On each sampling date, uprights were cut at the soil level within a 6-cm-diameter circle and placed in paper bags. When root samples were collected, below-ground stems and roots (combined) were removed with an auger $($ depth $=22 \mathrm{~cm}$, diameter $=6$ $\mathrm{cm})$, at the same location from which uprights had been cut, and bagged. Upon returning to the laboratory, upright samples were immediately placed into a drier at $80^{\circ} \mathrm{C}$ for a minimum of $5 \mathrm{~d}$. Root samples (including belowground stems) were washed carefully and bagged the same day, and dried. Dry samples were weighed and ground to 40 mesh using a Wiley mill.

CARbohydrate analysis. HPLC analysis was used to determine sucrose, glucose, fructose, and starch concentrations in 100-mg upright and root subsamples, according to the methodology described by Botelho and Vanden Heuvel (2005).

Flood Conditions. During flooding events, water and air temperature, water depth, water clarity, and DO above the tissue sample collection plots were measured periodically throughout the flooding duration. Water clarity was determined by measuring light penetration through the water to the vines using an underwater quantum sensor attached to a LI-1400 data logger (LI-COR, Lincoln, Nebr.). The quantum sensor was positioned parallel to the ground at the top of the vines, approximately $13 \mathrm{~cm}$ above the soil surface. Water depth was measured from the top of the vines to the surface of the floodwater so that light penetration data could be better correlated with attenuation and vine health. Dissolved oxygen and temperature of each flood were recorded in water above the sample collection plots using a DO meter (YSI 55; YSI, Yellow Springs, Ohio). Two subsample measurements were made above each repetition. These measurements were made on an approximate weekly basis during the month-long LW floods, on the only full day of the 48-h flash floods, and approximately every $3-4 \mathrm{~d}$ during variable-length harvest floods (harvest floods ranged from 3 to 27 $\mathrm{d}$ in duration). Presented data should not be considered absolute highs and lows for each site, as data were point measurements.

Data analysis. Least square means for pre- and post-flood samples were generated using SAS (SAS Institute, Cary, N.C.). Path analysis, a form of multivariate analysis, was performed on the data from the fall floods only (due to the larger number of observations), following the procedure of Bowley (1999), in order to evaluate the contributions of flood parameters to changes in total nonstructural carbo- hydrates ( $\triangle \mathrm{TNSC}$ ) during the flood. As there is a great deal of variation between sites in this study (due to cultivar, site conditions, site management, flood durations, water conditions, etc.), the results of this statistical analysis are only an indicator of the strength of contributing factors to $\triangle$ TNSC.

\section{Results and discussion}

EFFECTS OF "LATE WATER" FLOODS. Overall, TNSC of uprights exposed to LW floods either improved during the flood, or slightly decreased. Four of the seven LW floods resulted in a decrease in vine TNSC; however, decreases were $<10 \%$ on three of those sites (Table 1 ). We assumed that $\triangle T$ TNSC $>10 \%$ likely had a significant impact on the vine. Only one LW flood (Site 2) resulted in a substantial decrease $(-32 \%)$ in TNSC when the pre- and post-flood samples were compared. Of the three sites in which increases in TNSC were observed, increases were substantial at two of those sites (Site 1 in $2003=$ $+22 \%$; Site $3=+36 \%$ ).

Changes in TNSC appeared to be correlated with flood water temperature during LW floods. Site 2 had the greatest decrease in vine TNSC $(-32 \%)$, and was also the warmest flood measured (maximum measured temperature, $25.7^{\circ} \mathrm{C}$ ). This site did not hold water well and, as a result, the flood was shallow and warmed quickly. Significant increases in TNSC occurred at Site 1 in 2003 (maximum measured temperature, $18.1^{\circ} \mathrm{C}$ ) and Site 3 (maximum measured temperature, $21.5^{\circ} \mathrm{C}$ ). In 2003 and 2004, Site 1 was the only LW site with photosynthetically active radiation $(P A R)<1000 \mu \mathrm{mol} \cdot \mathrm{m}^{-2} \cdot \mathrm{s}^{-1}$ at the top of the vines in full sun. Interestingly, even with the dark water $\left(<400 \mu \mathrm{mol} \cdot \mathrm{m}^{-2} \cdot \mathrm{s}^{-1} \mathrm{PAR}\right)$, there was a significant increase in upright TNSC in 2003, and only a minor decrease in 2004 (Table 1).

Partitioning between carbohydrates was affected when pre- and post-flood samples were compared for all LW floods. Prior to flood application, soluble carbohydrates (glucose + fructose + sucrose) accounted for more than $70 \%$ of TNSC (data not shown) compared to $32 \%$ to $43 \%$ of TNSC after the flood. Not only were soluble carbohydrates likely respired during the flood, but increases in starch concentration during the flood (data not shown) may be attributed to the possible conversion of soluble 
Table 1. Influence of spring (late water, flash) and fall (harvest) flooding on changes in total nonstructural carbohydrates ( $\triangle$ TNSC) of cranberry upright tissue.

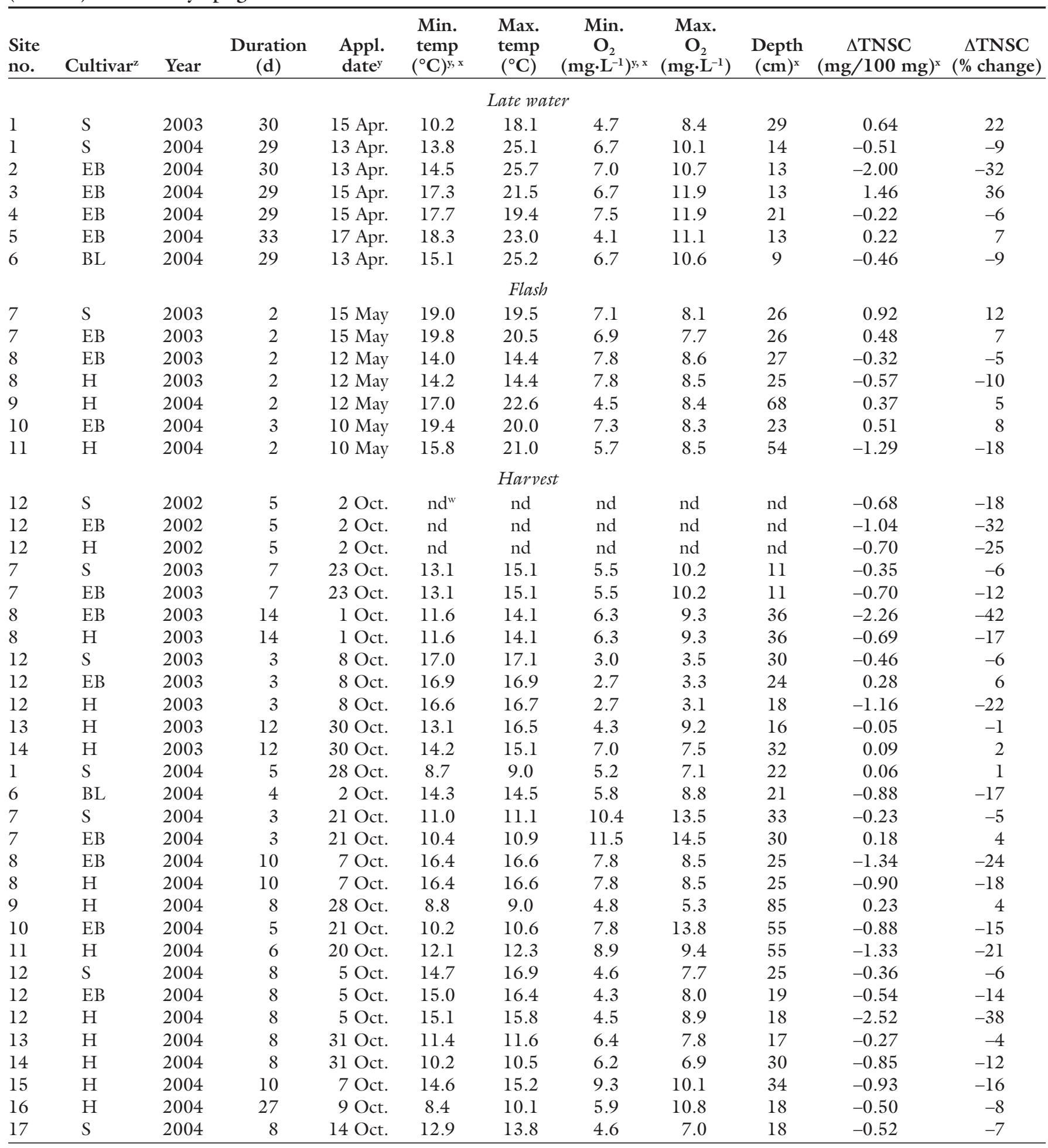

${ }^{2} \mathrm{~S}=$ 'Stevens'; EB = 'Early Black'; H = 'Howes'; BL = 'Ben Lear'.

'Appl. date $=$ application date $;$ Min. $=$ minimum $;$ Max. $=$ maximum $; \mathrm{O}_{2}=$ oxygen .

$\times\left(1.8 \times{ }^{\circ} \mathrm{C}\right)+32={ }^{\circ} \mathrm{F} ; 1 \mathrm{mg} \cdot \mathrm{L}^{-1}=1 \mathrm{ppm} ; 1 \mathrm{~cm}=0.3937 \mathrm{inch} ; 1 \mathrm{mg} / 100 \mathrm{mg}=1 \%$ dry weight.

"nd $=$ no data available. 
carbohydrates into starch. A similar result was reported in a greenhouse study simulating LW floods (Botelho and Vanden Heuvel, 2005). However, these partitioning changes in uprights may not be due to flood application; 'Stevens' and 'Early Black' sites have shown increases in starch concentration and decreases in soluble carbohydrate concentration at this time of the year regardless of whether they were exposed to a flood (Figs. 1-4).

In 2004, additional upright samples were removed from all LW sites 2 weeks after the post-flood collection date and analyzed for TNSC (data not shown). Generally, TNSC in uprights increased over the 2 -week post-flood period; however, this increase was generally due to substantial increases in starch rather than changes in soluble carbohydrate concentrations (<l mg/l00 mg).

In contrast to the results presented here, $\triangle$ TNSC has been reported to decrease drastically during a simulated LW flood using potted vines (Botelho and Vanden Heuvel, 2005). The differences between studies may be due to the degree of dormancy in the vines. While vines in both studies were subjected to the flood prior to terminal bud swelling, it is possible the potted vines in the greenhouse emerged from dormancy sooner due to warmer water temperatures. In the greenhouse study (Botelho and Vanden Heuvel, 2005), and at Site 2, we noted an unnatural elongation of some uprights. This is likely temperature related, or may be due to application of the flood at a slightly later phenological stage.

Late water floods have been anecdotally related to poor yields; however, with the exception of Site 2 in 2004, there was little evidence to support detrimental effects of this flood during the years of this study, although further study is required. We hypothesize that problems that cranberry growers report as associated with late water floods may be due to application of the flood at a slightly later phenological stage, as most growers apply these floods based on calendar date. Flood application by growing degree-day accumulation, rather than by calendar date, may be a more reliable method for determining application date and preventing vine damage.

EFFECTS OF "FLASH" FLOODS. Of the seven flash floods investigated, there was a decrease in upright TNSC

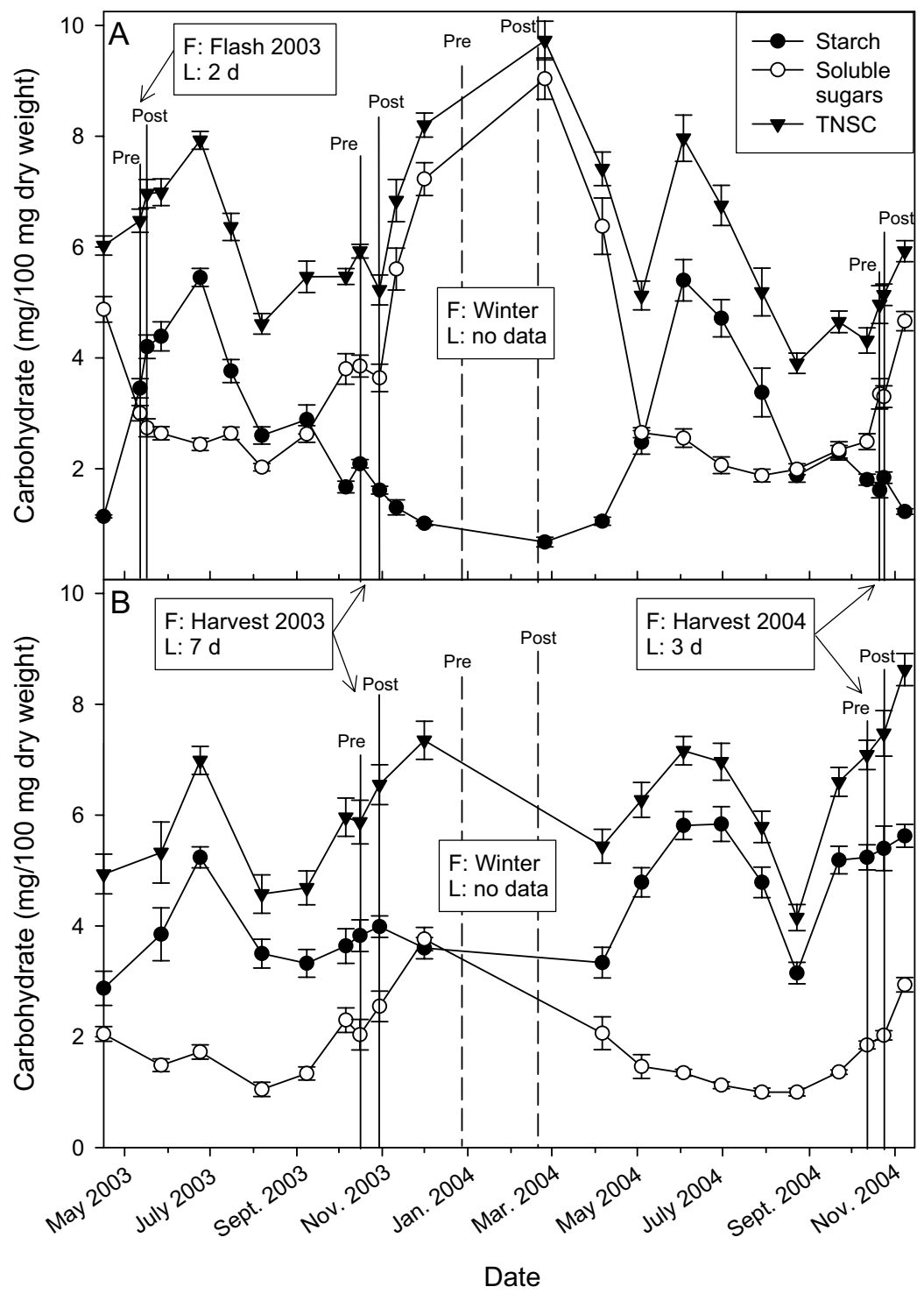

Fig. 1. Seasonal changes in starch, soluble sugars, and total nonstructural carbohydrate concentration of 'Early Black' cranberry uprights (A) and roots (B) at Site 7 . SE is represented by vertical bars, $\mathbf{n}=\mathbf{8}$ for each sampling date, $1 \mathrm{mg} / 100$ $\mathrm{mg}=1 \%$, Soluble sugars $=$ glucose + fructose + sucrose, TNSC $=$ total nonstructural carbohydrates, Pre $=$ pre-flood sample collection, Post $=$ post - flood sample collection, $\mathrm{F}=$ flood type, $\mathrm{L}=$ length of flood. Flood conditions are provided in Table 1.

between pre- and post-flood samples at three sites. However, at only one site did the flash flood detrimentally affect $\triangle$ TNSC substantially, with a reduction of $18 \%$ (Site 11, Table 1). It is unclear why uprights at this site were detrimentally affected, as flood duration, water temperature, DO, and water depth did not differ greatly from other sites where upright $\Delta$ TNSC was unaffected (Table 1 ). Increases in TNSC during the flash floods were as high as $12 \%$.

A flash flood was investigated at one site where carbohydrate accumulation patterns were being tracked throughout the season (Figs. 1 and 2). In May 2003, 'Early Black' uprights at Site 7 (Fig. 1A) exhibited a 22\% increase in starch after a flash flood was applied for pest control; however, this flood may not have caused the increase, as starch typically increases during the spring on nonflooded sites (Figs. 3 and 4; Hagidimitriou and Roper, 1994). The pattern of TNSC accumulation did not appear to be negatively affected by the flood, as TNSC concentrations increased by $7 \%$. 'Stevens' uprights sampled on the same bed at Site 7 had similar results (Fig. 2A). The only carbohydrate pattern change seen as 


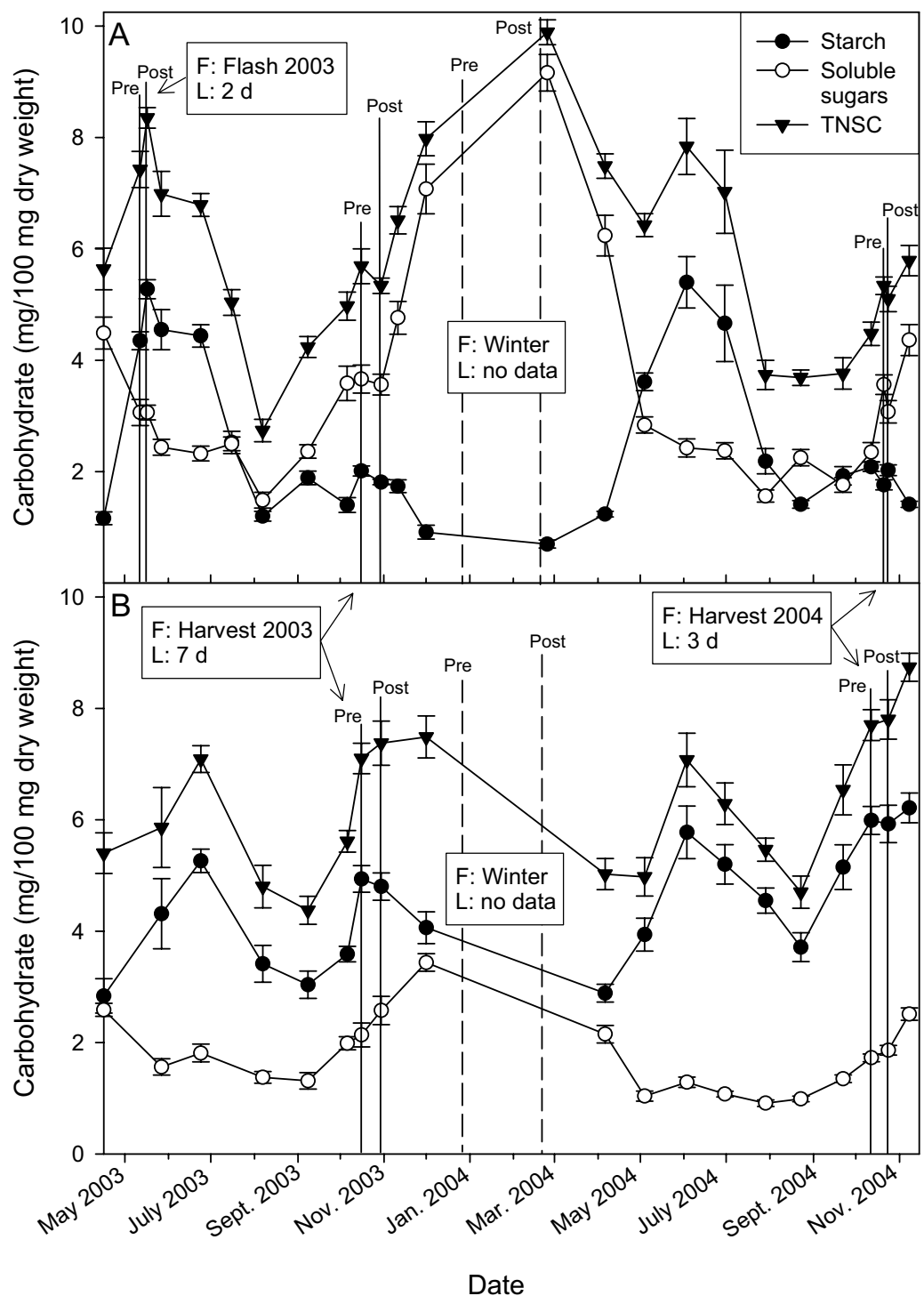

Fig. 2. Seasonal changes in starch, soluble sugars, and total nonstructural carbohydrate concentration of 'Stevens' cranberry uprights (A) and roots (B) at Site 7. $\mathrm{SE}$ is represented by vertical bars, $\mathrm{n}=8$ for each sampling date, $1 \mathrm{mg} / 100 \mathrm{mg}$ $=1 \%$, Soluble sugars $=$ glucose + fructose + sucrose, TNSC $=$ total nonstructural carbohydrates, Pre $=$ pre-flood sample collection, Post $=$ post-flood sample collec tion, $\mathrm{F}=$ flood type, $\mathrm{L}=$ length of flood. Flood conditions are provided in Table 1.

a result of this flood was an atypical increase in sucrose concentration in both cultivars (data not shown).

Partitioning among carbohydrates did not appear to be significantly affected by the use of a flash flood. The concentration of soluble carbohydrates either decreased slightly or remained the same, while the concentration of starch either remained similar or increased during the flood (data not shown). A similar pattern was noted on nonflooded sites at that time (Figs. 3 and 4).

Poor water clarity (i.e., low PAR penetration to the vines) has been time (Figs. 3 and 4), indicating that vines may have been able to recover quickly from the flood.

EFFECTS OF "HARVEST" FLOODS. On sites in which seasonal carbohydrate concentrations were continuously tracked over 2 years, four harvest floods were monitored. In 2003, the harvest flood applied to Site 7 (Fig. 1A) caused a $12 \%$ decrease in the TNSC concentration of 'Early Black' uprights (Table 1, Fig. 1A). Starch concentration of 'Early Black' uprights decreased by 23\% during this flood; however, decreases in starch concentrations were typical during the fall (Figs. 1-4; Hagidimitriou and Roper, 1994). In 'Stevens' uprights (Fig. 2A), a decrease of $6 \%$ in TNSC concentration caused a small interruption in the fall accumulation pattern. Root tissue sampled from both cultivars for the 2003 harvest flood at Site 7 (Figs. 1B and 2B) did not reveal any changes from the normal carbohydrate accumulation pattern. At Site 12, TNSC concentrations in 'Early Black' uprights (Fig. 3A) were not adversely affected by the 2003 harvest flood. A $20 \%$ increase in starch was observed, though increases in starch concentrations in the fall were normal (Figs. 1-4). TNSC and soluble sugar accumulation patterns in 'Stevens' uprights at Site 12 (Fig. 4A) appeared to be disrupted by the flood, with decreases of $6 \%$ and $12 \%$, respectively. Carbohydrate concentrations in roots of both cultivars were not affected by the 2003 harvest flood at Site 12 (Figs. 3B and 4B).

In 2004, TNSC concentrations in 'Early Black' uprights at Site 7 (Fig. IA) were not affected by the 3-d harvest flood. In 'Stevens' uprights (Fig. $2 \mathrm{~A})$, TNSC decreased by $5 \%$ and the accumulation pattern was disrupted by this flood. Root tissue sampled in 2004 at Site 7 (Figs. 1B and 2B) showed no pattern changes for both cultivars.

A loss of $14 \%$ of TNSC concentration and an apparent interruption in the fall accumulation pattern in 'Early Black' uprights (Fig. 3A) were seen as a result of the 2004 harvest flood at Site 12. Soluble sugars decreased by $24 \%$, which caused an interruption in normal fall carbohydrate pattern. 'Stevens' uprights (Fig. 4A) had a 6\% decrease in TNSC and 14\% decrease in soluble sugars. TNSC increased in root tissue of 'Early Black' (Fig. 3B) and 'Stevens' (Fig. 4B) at Site 12 . Overall, carbohydrate accumulation 


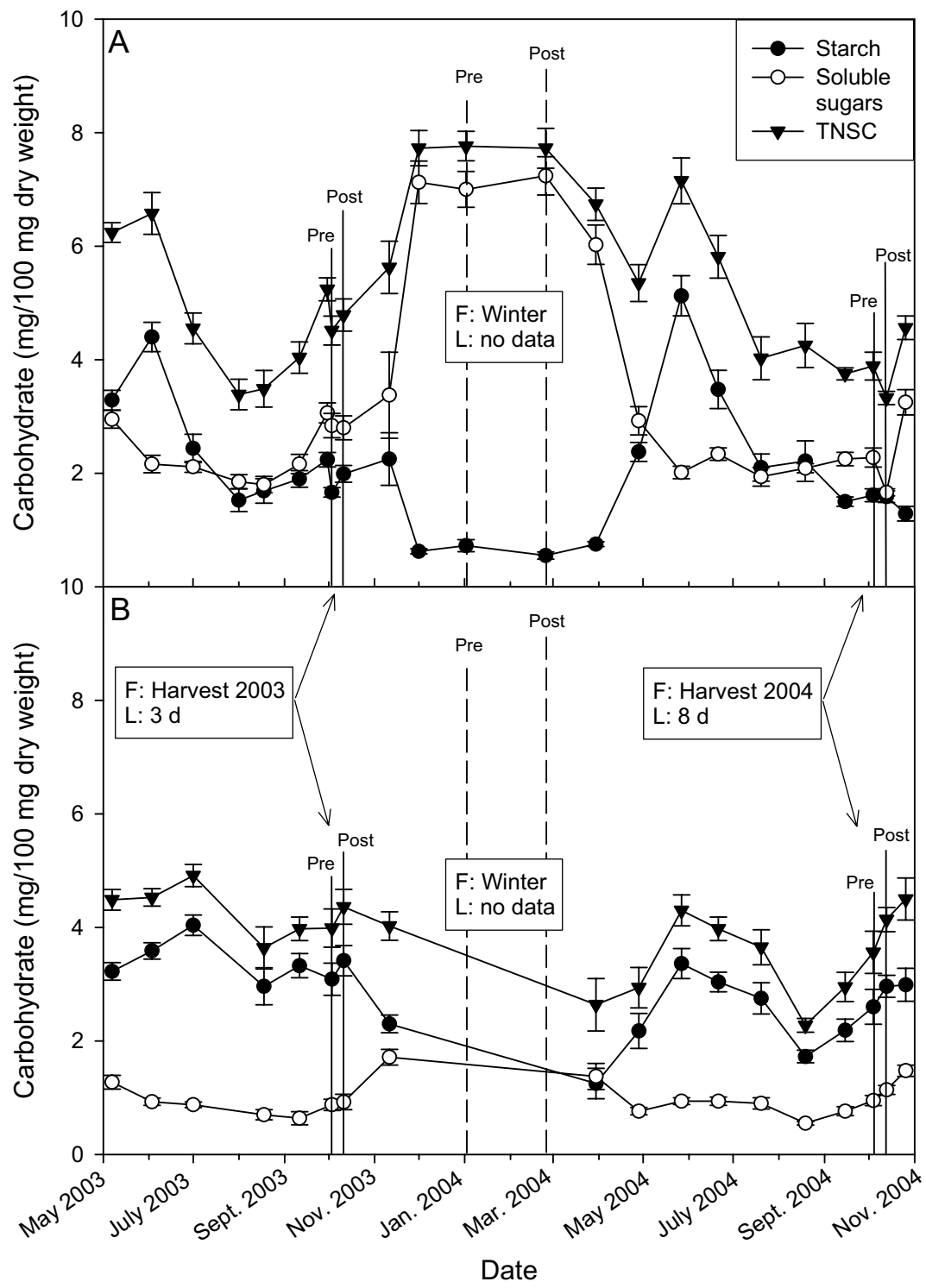

Fig. 3. Seasonal changes in starch, soluble sugars, and total nonstructural carbohydrate concentration of 'Early Black' cranberry uprights (A) and roots (B) at Site 12. SE is represented by vertical bars, $\mathbf{n}=\mathbf{8}$ for each sampling date, $\mathbf{1}$ $\mathrm{mg} / 100 \mathrm{mg}=1 \%$, Soluble sugars $=$ glucose + fructose + sucrose, TNSC $=$ total nonstructural carbohydrates, Pre $=$ pre-flood sample collection, Post $=$ post-flood sample collection. Flood conditions are provided in Table 1.

patterns in root tissue were not affected significantly by harvest floods.

Harvest floods were investigated at an additional three sites in 2002 , five sites in 2003 , and 13 sites in 2004 (Table 1). In general, fall floods had a negative impact on TNSC over the course of the harvest flood. The greatest decrease in TNSC was $42 \%$, caused by a 14-d flood on 'Early Black' at Site 8 (Table 1, Fig. 5). Other substantial decreases in TNSC occurred on 'Early Black' at Site 12 in 2002 $(-32 \%)$, 'Howes' at Site 12 in 2003 $(-22 \%)$, 'Howes' at Site 12 in 2004 $(-38 \%)$, 'Early Black' at Site 8 in 2004
$(-24 \%)$, and 'Howes' at Site 11 in 2004 $(-21 \%)$. Increases in TNSC during the fall flood were rare, with the largest increase occurring in 'Early Black' at Site 12 in $2003(+6 \%)$.

Data from Site 12 (containing 'Early Black', 'Stevens', and 'Howes') provide an opportunity for comparison of cultivars under similar flooding conditions. In 2002, TNSC decreased in all three cultivars during the 5 -d flood $(-18 \%,-32 \%$, and $-25 \%$ for 'Stevens', 'Early Black', and 'Howes', respectively). In 2003, 'Howes' at Site 12 had a $22 \%$ decrease in upright TNSC during the $3-\mathrm{d}$ flood, while
'Early Black' had an increase of 6\%. In 2004, 'Howes' again was detrimentally affected $(-38 \%)$ compared to 'Stevens' $(-6 \%)$ and 'Early Black' $(-14 \%)$. The flood at Site 12 is an early fall flood, generally starting within the first few days of October. A possible explanation may be that vines of different cultivars were at different phenological stages at the time of the flood. 'Early Black', an early ripening cultivar, may be closer to dormancy than other cultivars, and therefore not as susceptible to damage from floods, while 'Howes' may still be actively growing. In contrast, TNSC in 'Howes' growing on the same bed as 'Early Black' at Site 8 in 2003 decreased 17\% (Table 1, Fig. 5), while TNSC decreased $42 \%$ in 'Early Black'. Later floods (late October, early November) on 'Howes', while lengthy (12 d each), had little effect on TNSC (Table 1, Fig. 5 ). 'Early Black' and 'Stevens', growing on the same bed at Site 7 , reacted similarly to harvest floods (Figs. 1 and 2 ), exhibiting either a slight increase or decrease in TNSC. It is unclear why TNSC changes during flooding are inconsistent among sites within a given cultivar, although the hypothesis of a correlation between degree of dormancy and affect of flooding on TNSC warrants further investigation. The similarity in seasonal TNSC patterns between cultivars at the same site (Figs. 1 and 2; Figs. 3 and 4), as opposed to between cultivars at different sites, indicates that management practices likely have a significant effect on carbon production and partitioning in cranberry vines.

Path coefficient analysis indicated that, with the exception of flood depth, most flood parameters play a role in affecting $\triangle T N S C$ during the fall flood (Table 2), although due to variation between sites, these coefficients should only be used as an indicator of major effects. Flood duration, maximum recorded temperature, and minimum recorded DO concentration were all negatively related to $\triangle$ TNSC, while date of application (expressed as day of the year), minimum recorded temperature, and maximum recorded DO concentration were all associated with positive changes in TNSC.

Maximum recorded water temperature had the greatest negative impact on actual TNSC (Table 2), likely due to increased respiration with increasing water temperature. Although many sites with low water 


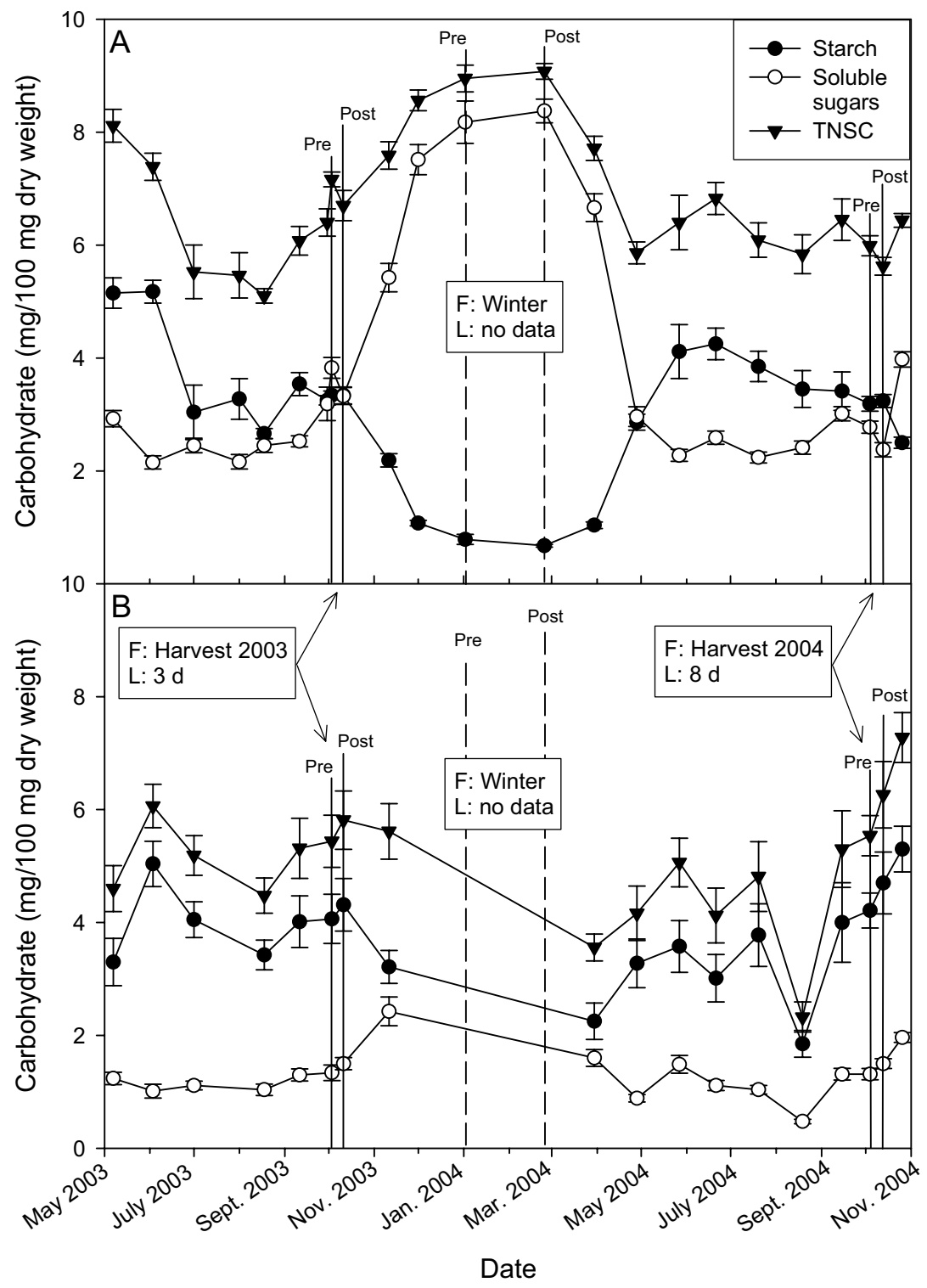

Fig. 4. Seasonal changes in starch, soluble sugars, and total nonstructural carbohydrate concentration of 'Stevens' cranberry uprights (A) and roots (B) at Site 12. $\mathrm{SE}$ is represented by vertical bars, $\mathbf{n}=\mathbf{8}$ for each sampling date, $1 \mathrm{mg} / 100$ $\mathrm{mg}=1 \%$, Soluble sugars $=$ glucose + fructose + sucrose, TNSC $=$ total nonstructural carbohydrates, Pre $=$ pre-flood sample collection, Post $=$ post - flood sample collection. Flood conditions are provided in Table 1.

temperatures during fall floods had comparatively small changes in TNSC (Site 1 in 2004, Site 9 in 2004), others with low temperature still had a significant decrease in TNSC (Site 11 in 2004), indicating that interactions of flood parameters may detrimentally impact TNSC of uprights.

While path coefficient analysis indicated that vines were negatively impacted by low DO, and positively impacted by high DO, the results are unclear. In a controlled environment study, a DO concentration of $8.5 \mathrm{mg} \cdot \mathrm{L}^{-1}$ was more detrimental to $\triangle$ TNSC compared to a DO concentration of $6.2 \mathrm{mg} \cdot \mathrm{L}^{-1}$ (Botelho and Vanden Heuvel, 2005) during a 21-d simulated LW flood. DO concentration of the floodwater at Site 12 in 2003 (Table 1) was significantly lower than the suggested minimum of $5.0 \mathrm{mg} \cdot \mathrm{L}^{-1}$ (Bergman, 1943) for the duration of the flood, but TNSC of 'Stevens' and 'Early Black' was not significantly impacted, perhaps due to the brevity of the flood. DO varies greatly during a flood and is dependent on weather conditions, water movement, and carbon exchange capacity of the vines.
Similar to the results from the spring floods, $P A R$ penetration to the vines appeared to have little effect on $\triangle T$ TNSC between pre- and post-flood samples (data not shown), although only two sites in this study had PAR levels $<400 \mu \mathrm{mol} \cdot \mathrm{m}^{-2} \cdot \mathrm{s}^{-1}$. As the light compensation point for uprights is low $\left(<30 \mu \mathrm{mol} \cdot \mathrm{m}^{-2} \cdot \mathrm{s}^{-1} \mathrm{PAR}\right)$ (Vanden Heuvel and Davenport, 2005), it is likely that vines can still be net carbon producers during the daytime in floods with dark water.

Date of flood application in the fall had a significant effect on $\triangle$ TNSC during the fall flood (Table 2, Fig. 5). Although there are some exceptions, floods applied in late October did not detrimentally affect upright TNSC to the same extent as floods applied earlier in the fall. A visual observation from Fig. 5 indicates that floods applied between 1 and 15 Oct. appear to have the most detrimental effect on the vines, while those applied between 15 Oct. and 1 Nov. appear to have less of an effect, and those remaining at sites after 1 Nov. appear to have little effect on vine TNSC. This observation likely reflects the phenological stage of the vines. Later in the fall, the vines are closer to dormancy and less physiologically active.

EFFECTS OF “WINTER" FLOODS. Winter floods were only investigated at sites where carbohydrate concentration was tracked on a seasonal basis. Although exact dates of flood application at Site 7 are unknown, upright TNSC increased December through March of the following season, due to an increase in soluble carbohydrates (Figs. 1A and 2A). TNSC of root tissue decreased during the winter (Figs. IB and $2 \mathrm{~B}$ ). Monitoring of a winter flood at Site 12 in early 2004 demonstrated that TNSC, starch, and soluble sugars were not significantly affected by this flood in 'Early Black' or 'Stevens' (Figs. 3A and 4A). Though pre-flood samples were collected on the day the flood was applied, it is uncertain exactly when the flood was completely removed from the site, as an ice layer remained above the vines when the floodwater was withdrawn. Post-flood samples were collected once the ice had melted completely. As all Massachusetts cranberry beds are flooded through parts of the winter, it is difficult to determine the effects of winter floods vs. normal $\triangle \mathrm{TNSC}$ patterns during that period. 

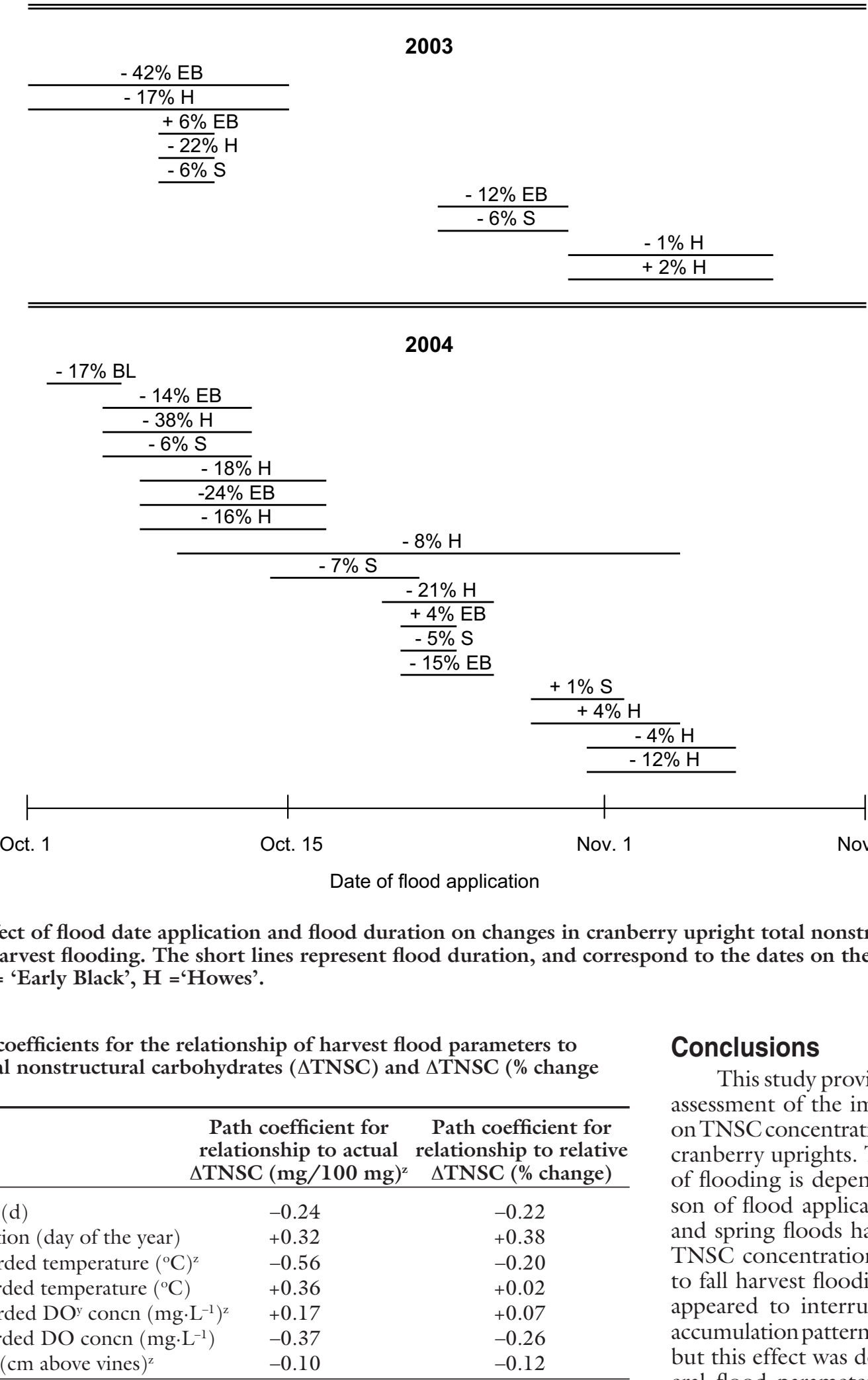

Fig. 5. The effect of flood date application and flood duration on changes in cranberry upright total nonstructural carbohydrate during harvest flooding. The short lines represent flood duration, and correspond to the dates on the bottom axis. $S=$ 'Stevens', EB = 'Early Black', H ='Howes'.

Table 2. Path coefficients for the relationship of harvest flood parameters to changes in total nonstructural carbohydrates ( $\triangle$ TNSC) and $\triangle$ TNSC (\% change over flood).

Flood parameters

Flood duration $(\mathrm{d})$

Date of application (day of the year) Maximum recorded temperature $\left({ }^{\circ} \mathrm{C}\right)^{x}$ Minimum recorded temperature $\left({ }^{\circ} \mathrm{C}\right)$ Maximum recorded $\mathrm{DO}^{y}$ concn $\left(\mathrm{mg} \cdot \mathrm{L}^{-1}\right)^{z}$ Minimum recorded DO concn $\left(\mathrm{mg} \cdot \mathrm{L}^{-1}\right)$

$\frac{\text { Depth of flood }(\mathrm{cm} \text { above vines })^{\mathrm{z}} \quad-0.10}{{ }^{2} \mathrm{mg} / 100 \mathrm{mg}=1 \% ;\left(1.8 \times{ }^{\circ} \mathrm{C}\right)+32={ }^{\circ} \mathrm{F} ; 1 \mathrm{mg} \cdot \mathrm{L}^{-1}=1 \mathrm{ppm} ; 1 \mathrm{~cm}=0.3937 \text { inch }}$ ${ }^{\mathrm{DOO}}=$ dissolved oxygen

\section{Conclusions}

This study provides a preliminary assessment of the impact of flooding on TNSC concentration in field-grown cranberry uprights. The overall effect of flooding is dependent on the season of flood application. The winter and spring floods had little effect on TNSC concentrations in comparison to fall harvest flooding. Fall flooding appeared to interrupt the autumnal accumulation pattern of carbohydrates, but this effect was dependent on several flood parameters, such as flood duration, time of application, water 
temperature, and DO concentration. In addition, the opportunity for further carbohydrate accumulation in late fall may be lost due to harvest flooding, and it is likely that the vines have lesser amounts of carbohydrates for maintenance respiration through the winter and for spring growth as a result. These losses may become evident once spring growth begins developing. As TNSC was often negatively affected by flooding, the possibility exists for a direct negative relationship between fall flooding and yield of the following season's crop.

Additional studies in controlled environments may provide a better idea of how specific flood parameters affect carbohydrate losses. The examination of interactions of specific flood parameters, such as DO concentration, water temperature, $P A R$ penetration to vines, and timing of flood application within a season, would provide insight into how these factors affect floodrelated carbohydrate loss. Specific flooding schedules may be required for each cranberry cultivar/site based on accumulation of growing degree days. Additional research is needed to determine the relationship between flooding and yield.

Recommendations for cranberry growers in northeastern North America need to be adjusted to reflect recent discoveries. We propose the following recommendations for growers based on our observations:

1. Short floods have the least detrimental effect on carbohydrate concentration of uprights, particularly during fall floods.

2. Cooler flood water likely reduces vine respiration, resulting in lower carbohydrate usage by the vine. For that reason, deeper floods are recommended due to the ability of a deeper flood to maintain cooler water temperatures for a longer period of time. Recharging of floods from the water source may also help reduce water temperature on the site.

3. Spring floods, particularly 48 h flash floods, should be considered a viable pest management tool on a healthy site.

4. Fall floods, particularly extended ones, should be applied as late into the harvest season as possible.

In order to further modify these recommendations, replicated experiments need to be conducted that ideally compare nonflooded and flooded treatments on the same site, so that direct comparisons among treatments within the same site can be made.

\section{Literature cited}

Averill, A.V., M.M. Sylvia, C.C. Kusek, and C.J. DeMoranville. 1997. Flooding in cranberry to minimize insecticide and fungicide inputs. Amer. J. Alternative Agr. $12: 50-54$

Baumann, T.E. and G.W. Eaton. 1986. Competition among berries on the cranberry upright. J. Amer. Soc. Hort. Sci. 111:869-872.

Bergman, H.F. 1943. The relation of ice and snow cover on winter-flooded cranberry bogs to vine injury from oxygen deficiency, p. 3-24. In: H.J. Franklin, H.F. Bergman, and N.E. Stevens (eds.). Weather in cranberry culture. Mass. Agr. Expt. Sta. Bul. 402.

Birrenkott, B.A., C.A. Henson, and E.J. Stang. 1991. Carbohydrate levels and the development of fruit in cranberry. J. Amer. Soc. Hort. Sci. 116:174-178.

Birrenkott, B.A. and E.J. Stang. 1990. Selective flower removal increases cranberry fruit set. HortScience 25:1226-1228.

Botelho, M.R. and J.E. Vanden Heuvel. 2005. High dissolved oxygen concentration of floodwater reduces carbohydrate concentration of cranberry uprights during flooding. HortScience 40(3):569-573.

Bowley, S.R. 1999. A hitchhiker's guide to statistics in plant biology. Plants et al., Inc., Guelph, Ont., Canada.
Cockfield, S.D. and D.L. Mahr. 1992. Flooding cranberry beds to control blackheaded fireworm (Lepidoptera: Tortricidae). J. Econ. Entomol. 85:2383-2388.

Crane, J.H. and F.S. Davies. 1989. Flooding responses of Vaccinium species. HortScience 24:203-210.

DeMoranville, C.J., H.A. Sandler, D.E. Shumaker, A.L. Averill, F.L. Caruso, M.M. Sylvia, and D.M. Pober. 2005. Fall flooding for management of cranberry fruitworm (Acrobasis vaccinii) and dewberry (Rubus hispidus) in Massachusetts cranberry production. J. Crop Protection 24:999-1006.

Eck, P. 1990. The american cranberry. Rutgers Univ. Press, New Brunswick, N.J.

Hagidimitriou, M. and T.R. Roper. 1994. Seasonal changes in nonstructural carbohydrates in cranberry. J. Amer. Soc. Hort. Sci. 119:1029-1033.

Marucci, P.E. and H.J. Moulter. 1971. Oxygen deficiency kills cranberry insects. Cranberries 35:13-15.

Roper, T.R. and N. Vorsa. 1997. Cranberry: Botany and horticulture. Hort. Rev. 21:215-249.

Stevens, N.E. and N.E. Thompson. 1942. Factors influencing injury to cranberry plants during flooding. Trans. Wisc. Acad. Sci. Arts Lett. 34:73-81.

Strik, B.C., T.R. Roper, C.J. DeMoranville, J.R. Davenport, and A.P. Poole. 1991. Cultivar and growing region influence return bloom in cranberry uprights. HortScience 26:1366-1367.

Vanden Heuvel, J.E. 2005. Flood water temperature and duration affect nonstructural carbohydrate concentration of cranberry uprights and roots. HortScience 40(4):1127 (Abstr.).

Vanden Heuvel, J.E. and J.R. Davenport. 2005. Effects of light, temperature, defoliation and fruiting on carbon assimilation and partitioning in potted cranberry. HortScience 40(6):1699-1704. 